UNDERGRADUATE RESEARCH IN NATURAL AND CLINICAL SCIENCE AND TECHNOLOGY (URNCST) JOURNAL Read more URNCST Journal articles and submit your own today at: https://www.urncst.com

\title{
Celebrating Our One-Year Anniversary: Highlights of the URNCST Journal
}

Jae Hyun Byun, BSc, MSc Student [1], Rodrigo Noorani, BSc Student [1], Umair Majid, MSc, MEd, PhD Student [2], Jeremy Y. Ng, MSc, PhD Student [3]*

[1] Deputy Editor, URNCST Journal, Toronto, Ontario, Canada

[2] Managing Editor, URNCST Journal, Toronto, Ontario, Canada

[3] Editor-in-Chief, URNCST Journal, Toronto, Ontario, Canada

*Corresponding Author: editor@urncst.com

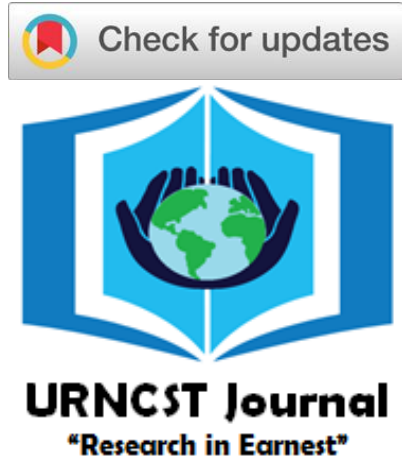

\begin{abstract}
The Undergraduate Research in Natural and Clinical Science and Technology (URNCST) Journal was founded in July 2017 and has strived to be recognized as the leading publisher for undergraduate research conferences and case competitions around the world since its inception. The journal provides undergraduate researchers with the opportunity to showcase their research to an international audience in the formats of peer-reviewed research abstracts and manuscripts. This editorial was co-written by senior editors at the URNCST Journal to highlight the publication's accomplishments leading up to its one-year anniversary while also sharing with our audience - both authors and readers - what they can look forward to in the upcoming year! We are extremely proud the degree of success that the URNCST Journal has experienced so far, and continue to champion for the importance of undergraduate research, considering that all major research discoveries were made by a researcher who was once an inspired undergraduate student. On behalf of the entire journal, we look forward to continue showcasing the research that undergraduate researchers have to offer internationally.
\end{abstract}

Keywords: annual highlights; undergraduate research; undergraduate publication; URNCST Journal

\section{Introduction}

Academic institutions are constantly striving to provide their students with a fulfilling and enriching educational experience. An important component of this process has been to include a research placement component to the undergraduate curriculum. Such experiences provide the opportunity for undergraduate students to create a project outside of the traditional classroom learning environment, as they are allowed to actively participate in one or more steps of the research process [1-2]. Though the idea of integrating research experience into undergraduate education has been around since the nineteenth century, its current popularity has been on an exponential rise.

Yet, despite the increasing number of undergraduate students that engage in research yearly, many of these students may fail to understand a crucial component essential to their research experience: peer-review and publishing. The reasons for this vary; a unanimous theme has been attributed to the lack in time and commitment to a given research project. Unfortunately, this often results in many young researchers never experiencing these final two steps of the research process until they near graduation of their first graduate degree, which inherently makes it difficult for an undergraduate student to truly understand the full process of research prior to making a decision to pursue gradu- ate studies. Nonetheless, provided that an undergraduate researcher has collected, analyzed, and interpreted data, and contributed their writing for inclusion in a manuscript, it is only appropriate that they are provided with the opportunity to receive peer-reviewed feedback and be exposed to the experiences that lead up to the publication of their findings.

\section{Objectives of the URNCST Journal}

Founded by Jeremy Ng, the URNCST Journal was first established in July 2017 to provide undergraduate researchers with a meaningful platform to showcase their research findings to a global audience that includes their peers, mentors, and members of graduate and professional program admission committees. The primary objective of the URNCST Journal is to publish abstract books for undergraduate-level conferences and case competitions in the disciplines of natural and clinical science and technology. The journal endeavoured since its inception to minimize the time between submission and providing the author with a peer-reviewed decision, as this provides a significant advantage to undergraduate student authors. A faster turnaround time allows undergraduate students to sooner showcase their work to a global audience and to their admissions committee. This proves especially advantageous for young 
UNDERGRADUATE RESEARCH IN NATURAL AND CLINICAL SCIENCE AND TECHNOLOGY (URNCST) JOURNAL Read more URNCST Journal articles and submit your own today at: https://www.urncst.com

researchers who want to demonstrate their research findings in written-form when applying for further education, scholarships, or new research placements and employment.

Moreover, the URNCST Journal team developed a unique publishing model which contrasts the vast majority of other undergraduate-level publications. Instead of publishing manuscripts submitted directly to the journal, we work with the planning committees of undergraduate research conferences and case competitions to publish an abstract book containing the abstracts of research accepted for presentation at the event. In joint agreement with the planning committees, only an agreed-upon number of winners of oral and/poster competitions at the given research event are provided with the opportunity to publish their full-article manuscript in the URNCST Journal, ensuring that such an opportunity remains highly prestigious for undergraduate researchers.

\section{URNCST Journal One Year Highlights}

To date, the URNCST Journal has accomplished several key achievements as our dedicated team continues to evolve and innovate the academic journal. Today, the URNCST Journal is arguably recognized as the leading publisher of undergraduate conferences in Canada, and our team has future plans to expand to other regions of the world. The team leading the URNCST Journal has been successful in receiving and utilizing nearly \$10 000 CAD of support through granting agencies, including the Government of Canada, allowing the publication to grow its readership, provide new opportunities to undergraduate researchers, and expand our operations to other regions of the world. Furthermore, to our knowledge, the URNCST Journal is the only undergraduate research journal that is a CrossRef member, and among very few undergraduate publications that issue digital object identifiers and index published articles. In only one year, over 200 high-quality research abstracts have been published in the URNCST Journal, the majority of which were presented at highlyprestigious undergraduate conferences held in Canada and Europe. For example, the URNCST Journal has published for the Canadian Undergraduate Conference on Healthcare $(\mathrm{CUCOH})$, the largest undergraduate healthcare conference in Canada, for SCINAPSE Undergraduate Science Case Competition, the largest Canadian science case competition, as well as the Student Medical Summit at the University College Dublin, the largest annual undergraduate medical conference held in Ireland.

Yet, another achievement to highlight is the establishment and growth of our editorial board. Comprised of graduate-level students and degree holders as well as highly research-oriented undergraduate students, the editorial board is comprised of a team of staff that hold numerous and varied valuable experiences in their own professional careers. While all editorial board members have significant research experience, some also hold experience relating to entrepreneurial ventures, marketing, government agencies, and non-profit organizations. Our editorial board works collectively to attract high-quality undergraduate research conferences and case competitions to form long-term partnerships with the URNCST Journal and assign potential reviewers to submitted manuscripts, provide feedback to authors, and offer high-quality peer-review for the improvement of content to be published in the journal. Since its inception, the URNCST Journal has roughly quintupled its team of staff from 8 at the point of inception to nearly 40 individuals today.

The editorial board consists of several roles which provide the needed skillsets to advance the URNCST Journal's mission. These include the following: editor-in-chief, managing editor, deputy editors, Associate Editors, Development and Communications Liaison, and Editorial and Advisory Board directors and Members. The Editor-in-Chief and the Deputy Editors provide constant supervision and manage the processing of manuscripts from submission to publication. Other members of the editorial board provide assistance in corresponding and collaborating with authors and its reviewers and/or work on other special projects that help ensure that the journal remains an innovative and growing publication. The journal's team also includes a number of Managers (operational and engagement) responsible for a team of journal assistants. This team collectively assists with outreach to different academic organizations across email and social media platforms in order to spread awareness of the URNCST Journal to both local and international divisions. Overall, the collaborative team effort has been integral to the achievements and successes experienced by the URNCST Journal.

\section{Research Abstract Competition}

As part of a united vision to support undergraduate students, the URNCST Journal launched the inaugural URNCST Researcher Abstract Competition in the summer of 2018. The competition was established to serve as an opportunity for any undergraduate researcher around the world to submit an abstract in the area of science and technology research completed during their undergraduate years. By allowing students to participate in the competition online, it offers the chance for undergraduate students to have their research published in the format of an abstract following rigorous peer-review by the journal's team of peer-reviewers without a need for the student to incur the costs of travel, accommodation, and poster creation, which are often required to attend undergraduate conferences hosted at a physical venue. This competition is just one example of how the URNCST Journal expanded the opportunities available to support the professional development of undergraduates in their academic and research pursuits.

Submitting an abstract to the competition is a very simple and straightforward process. Students are required to submit an abstract containing 300 words or less based on a template that can be downloaded from the journal's website. Eligible undergraduate authors must have partaken in 
UNDERGRADUATE RESEARCH IN NATURAL AND CLINICAL SCIENCE AND TECHNOLOGY (URNCST) JOURNAL Read more URNCST Journal articles and submit your own today at: https://www.urncst.com

academic research under the supervision of a principle investigator appointed at an academic institution, and the student's research must be conducted in an academic discipline within the scope of the journal. All submitted abstracts are then assessed by two qualified peer-reviewers, and their assessment and feedback is provided to the author of each abstract. Accepted abstracts are then subsequently published in a single abstract book on a pre-specified date, providing participants with the opportunity to receive a published abstract. No limits are placed on the number of abstracts that can be published, as this competition is designed to provide undergraduate researchers who submit abstracts of high-quality research the opportunity to publish their work. However, authors of highest-quality research are subsequently invited to publish a full-article manuscript that expands on the content contained within their abstract.

\section{Call for Submissions}

As the URNCST Journal celebrates its one-year anniversary, the publication's staff want to take this opportunity to announce our call for submissions for the upcoming year beginning with the next (August 2018) issue. The journal welcomes the opportunity to work with planning committees of undergraduate research conferences and case competitions internationally that accept abstracts relating to a broad range of scientific disciplines including but not limited to: biology; chemistry, earth and environmental sciences; biotechnology; physics; medical sciences; clinical sciences; health sciences; and clinical medicine.

Furthermore, the URNCST Journal also invites individual undergraduate researchers to participate in the URNCST Research Abstract Competition by submitting an abstract containing primary research, a review, or a research protocol. The submission of primary research abstracts should contain original research that is within the scope of the journal. Undergraduate researchers submitting a review abstract should note that their abstract should pertain to the literature that concisely summarizes and evaluates a specific field within the scope of the journal. Finally, research protocol abstracts submitted to the URNCST Journal should contain a research question and methodology that describes the feasibility of a proposed research study that is scheduled to be undertaken.

\section{Conclusion}

Exactly one year ago the URNCST Journal was founded with the goal of becoming the ideal undergraduate research journal, and we sincerely believe that this has become true in many regards based on our unique publishing model and innovations. Beyond the numerous successes achieved by the URNCST Journal, our staff are most proud of the fact that the foundation of the publication has provided both graduate and undergraduate students with meaningful and educationally-enriching opportunities. The establishment of the journal has enabled our staff with an interest and knowledge in the publishing industry to join our team and apply and hone their skills, improve their networking, communication and outreach skills, and make valuable contributions to the advancement of undergraduate research as a whole. Furthermore, the publication has provided the opportunity for undergraduate conferences and case competitions to showcase their delegates' research and build a legacy for their event, which in some cases, has been taking place annually for more than a decade without working with a publisher. Lastly, and more importantly, we are especially privileged and honoured to be the publisher of over 200 abstracts over the past year, containing many authors who had no prior opportunity to experience their research being formally peer-reviewed and published. As we continue to celebrate the successes of both our editorial team and authors over the first year since the establishment of the URNCST Journal, we also look forward to the continued growth of the URNCST Journal over the upcoming months and years as we showcase the valuable undergraduate research the world has to offer.

\section{List of Abbreviations}

URNCST: Undergraduate Research in Natural and Clinical Science and Technology

\section{Conflicts of Interest}

The author(s) declare that they have no conflicts of interest.

\section{Authors' Contributions}

JHB: contributed to the conceptualization and drafting of the manuscript.

$\mathrm{RN}$ : contributed to the drafting and editing of the manuscript

UM: contributed to the editing of the manuscript

JYN: contributed to the conceptualization and editing of, and supervised the writing of the manuscript.

\section{Acknowledgements}

We gratefully acknowledge the entire URNCST Journal team as follows: the Editorial and Advisory Board Directors (Humayun Ahmed, Sohaib Ahmed, and Sophia Glisch), the Associate Editors (Mehrdad Azimi, Edmond Chiu, Shaidah Deghan, Laura Mawdsley, Desmond She, Mark Tenn, David Werstler, and Jennifer Williams), the Development and Communication Liaison (Karen $\mathrm{Ng}$ ), the Editorial and Advisory Board members (Jamie Ghossein, Jonathon Hunter, and Rosemary James), the Operations Manager (Amandeep Singh Lubana and Sahil Thind), the Engagement Manager (Molly Cowls), the Editorial and Research Assistants (Ayomide Fakuade and Jessica Saini), the Engagement Officers (Saameh Siddique, Archit Jain, Allison Choi, Tashi Rastogi, Seun Fagbamila, Tuba Hyder, Jievi Wang, Reta Meng, and Varnikaa Gupta), and our Journal Ambassadors (Suman Banik, Chris Yan, Srijan Sahu, Niall Dalton, Abhi Aggarwal, and Aditya Sharma). We also gratefully acknowledge all of the planning committee members and presenting authors at all of the conferences 
UNDERGRADUATE RESEARCH IN NATURAL AND CLINICAL SCIENCE AND TECHNOLOGY (URNCST) JOURNAL Read more URNCST Journal articles and submit your own today at: https://www.urncst.com

and case competitions for whom we published. We look forward to continuing our long-term partnership with them and thank them for providing us with the opportunity to serve as the publisher for their research abstracts.

\section{References}

[1] Boyer Commission on Educating Undergraduates in the Research University (Carnegie Foundation for the
Advancement of Teaching), Reinventing Undergraduate Education: A Blueprint for America's Research Universities, 1998 (http://notes.cc.sunysb.edu/Pres/ boyer.nsf).

[2] Petrella, J. K., \& Jung, A. P. (2008). Undergraduate Research: Importance, Benefits, and Challenges. International Journal of Exercise Science, 1(3), 9195.

\section{Article Information}

Managing Editor: Jeremy Y. Ng

Article Dates: Received Jul 15 18; Published Jul 1718

\section{Citation}

Please cite this article as follows:

Byun JH, Noorani R, Majid U, Ng JY. Celebrating our one-year anniversary: Highlights of the URNCST Journal. 2018 Jul 17: 2(7). https://urncst.com/index.php/urncst/article/view/68

DOI Link: https://doi.org/10.26685/urncst.68

\section{Copyright}

(C) Jae Hyun Byun, Rodrigo Noorani, Umair Majid, Jeremy Y. Ng (2018). Published first in the Undergraduate Research in Natural and Clinical Science and Technology (URNCST) Journal. This is an open access article distributed under the terms of the Creative Commons Attribution License (https://creativecommons.org/licenses/by/4.0/), which permits unrestricted use, distribution, and reproduction in any medium, provided the original work, first published in the Undergraduate Research in Natural and Clinical Science and Technology (URNCST) Journal, is properly cited. The complete bibliographic information, a link to the original publication on http://www.urncst.com, as well as this copyright and license information must be included.

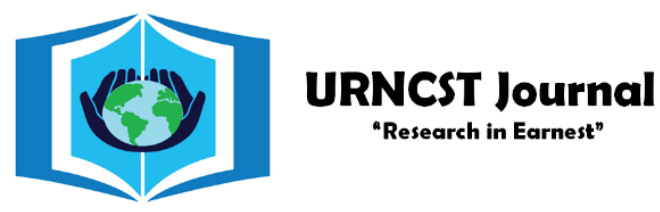

\section{Funded by the Government of Canada}

\section{Canadà}

Do you research in earnest? Submit your next undergraduate research article to the URNCST Journal!

| Open Access | Peer-Reviewed | Rapid Turnaround Time | International | | Broad and Multidisciplinary | Indexed | Innovative | Social Media Promoted |

Pre-submission inquiries? Send us an email at info@urncst.com | Facebook, Twitter and LinkedIn: @URNCST Submit YOUR manuscript today at https://www.urncst.com! 